Lesław Polny*, Ewelina Wójciak*

\title{
The Theory of Pseudo-Radiation Local Emitters Value of Properties with a Differential Propagation of Prices Wave**
}

\section{Introduction}

The shape property value of each segment is a function of resultant vectors corresponding factors price-determining. Estimation structural coefficients of the analytic model, confirmed by empirical value parameters stochastic, shows the deterministic importance location in the context of their value. Problem distribution prices in space was and is the subject of many direct or indirect scientific discussions, among others $[1-3,6,15,10,12-14,16]$, but in era permanently increasing real estate prices do not continue its topicality. Current knowledge in file property valuation led to the conclusion, that the level value is the highest in the center and decreases towards periphery. The author of this thesis rightly also notes that in larger cities can be clearly identify, outside the main center city, district centers [8]. They may cause, that radiation propagation of prices wave, transmitted as it were by a single emitter (city center) is refracted coexistence districts center with strong interference extreme. The statement so, that prices drop is not uniform; shapes it because system main arterial roads in the city and places their intersection with trade and service centers of second or third row [5] is over-generalization phenomenon spectral distribution prices. This was a solid foundation for the study, the aim of which was to verify the original theory of propagation of wave prices. In its outline the authors accept the assumption, that on a right-area real estate market exist at least two emitters prices, so points, on which unit prices rising (emitters progressive) or decrease (emitters regressive) in pseudo-radial. By this, we mean not uniform changes in prices in relation to the allocation of real estate in monitored space of variable development trends. It is further assumed, that wave prices propagated by progressive emitters have a lower amplitude and frequency vibration, while transmitted through regressive emitters are characterized by high beginning frequency and a strong damping vibrations in the first phase with parallel relatively high amplitude. This study does not take research emitters price other than a point, despite the fact that both linear (along roads, tram lines etc.) and superficial (around airports, parks etc.) in the authors opinion share rules propagation of wave prices of a point emitters.

\footnotetext{
* AGH University of Science and Technology, Faculty of Mining Surveying and Environmental Engineering, Department of Geomatics, Krakow, Poland

** This study has received the financial support from the statutory research no. 11.11.150.006
} 


\section{Methodology of Verification Conception}

The licensed professional group responsible for estimating property value are real estate appraisers. In part of good practice, they should reach out for new, often even innovation technological solutions, guaranteeing acquisition information not only about subject evaluation, but also about structure right-subject real estate market. As we read in International Valuation Standards: real estate appraiser should have access to advanced systems of collecting information [9]. One of them is the Geographic Information System. It allows considering distribution property prices in space not only with quantitative data, as done before, but also basis on visual interference. IVSC point out, that use GIS to valuation real estates is recommended and should become common practice [4].

In view of dynamic development algorithms property valuation, which is accompanied by not slower flowering possibilities Geography Information System, both fields applied to verify theory of pseudo-radiation local emitters property values with assuming differential propagation wave prices.

As test material was adopted data about real estate premises located in Krakow, available for free portal OpenStreetMap. Their preparation was made in open structure QGIS, implementing OSM plugin allows download suitable layers of geoinformation about apartments. SpatiaLite base was established basis on topology stored in file ".osm". Finally, test material concentrated in shapefile file, thus allowing for a comparison of algorithms estimating wave prices in free QGIS application with commercial ArcGIS.

Verification of pseudo-radiation local emitters property values consists in taking district centers, where are observed extreme prices. In the theory assumed cause, that propagation transmitted wave prices is neither steady nor uniform trends. Therefore, research pseudo-radiation involves the falsification thesis stipulating, that real estate value is the highest in the center and decreases in periphery direction [8] without indirect changes tendency of fluctuation of property prices. So, should take at least one emitter regressive and one progressive. Then simulate wave radiation emanating throughout the monitored area. Wavelength should be equal, but allowed its increase or reduction in order to maintain a relatively coincident with number test data (describe offer prices) falling within the scope $\left(\lambda_{i}\right)$. For purpose, this analysis is taken as test data the offer prices. In separate studies the authors of this research show, that in monitored space "negotiation filed" at an around of 5\%. In progress, this study is planned a complete change offer prices on transaction prices.

Test conception brought so to generate appropriate buffer around local emitters, which have been established in form rings of predefine dimeter and the beginning ring $\left(r_{b, i}\right)$ is expressed in formula:

$$
r_{b, i}=\sum_{i=1}^{k-1} \lambda_{i-1}
$$


while $\left(r_{e, i}\right)$ is complement the initial limit circle $\left(r_{b, i}\right)$ of length $i$-th wave $\left(\lambda_{i}\right)$ and is given by model:

$$
r_{e, i}=r_{b, i}+\lambda_{i}=\left(\sum_{i=1}^{k-1} \lambda_{i-1}\right)+\lambda_{i}=\sum_{i=1}^{k} \lambda_{i}
$$

Construction spatial query for objects, whose centroid is located within the $\left(i\right.$-th) wave radiation, allows its scope $\left(\lambda_{i}\right)$ set:

- number residential $\left(l_{i}\right)$,

- minimum unit price $\left(c_{i \min }\right)$,

- maximum unit price $\left(c_{i \text { max }}\right)$,

- average unit price $\left(\hat{c}_{i}\right)$,

- variance unit prices $\left(\sigma_{i}^{2}\right)$.

Variance in this case should be identified first and foremost with diversity market characteristic of real estates including falling within a singles wave prices, because shape unit price is a function of many variables, not only location, for the assuming arbitrarily, but with high probability is the most deterministic.

The theory of pseudo-radiation local emitters' value of properties is appropriate, when analytic function approximating average unit prices $\left(\hat{c}_{i}\right)$ is not monotonic, i.e. when for regressive emitters there is no condition (3), and for progressive there is no condition (4):

$$
\begin{aligned}
& \widehat{c}_{1} \geq \widehat{c}_{2} \geq \cdots \geq \widehat{c}_{k} \\
& \widehat{c}_{1} \leq \widehat{c}_{2} \leq \cdots \leq \widehat{c}_{k}
\end{aligned}
$$

Differential propagation wave prices occur, when $\forall \hat{c}_{i}\left(\lambda_{i}\right)>0$ difference dispersion coefficient averages unit prices from neighboring waves length $\lambda_{i}$ and $\lambda_{i+1}$ is not equal difference dispersion coefficient another pairs at total length emitting wave $\lambda_{i+1}+\lambda_{i+2}$. Differential wave in the author's theory is so fulfilled fallowing relation:

$$
\frac{\sqrt{\sigma_{1}^{2}}}{\widehat{c}_{1}}-\frac{\sqrt{\sigma_{2}^{2}}}{\widehat{c}_{2}} \neq \frac{\sqrt{\sigma_{2}^{2}}}{\widehat{c}_{2}}-\frac{\sqrt{\sigma_{3}^{2}}}{\widehat{c}_{3}} \neq \cdots \neq \frac{\sqrt{\sigma_{k-1}^{2}}}{\widehat{c}_{k-1}}-\frac{\sqrt{\sigma_{k}^{2}}}{\widehat{c}_{k}}
$$

or:

$$
\Delta \hat{Y}_{1,2} \neq \Delta_{2,3} \neq \cdots \neq \Delta_{k-1, k}
$$

Process estimation real estate values is saddled factors, which cannot be included in valuation models, which have a negative impact on accuracy result. It should also be emphasized, that value is derived from prices resulting from the game of supply and demand, so changing vary dynamic. 
Inaccuracy estimation makes the differential equation emission wave prices:

$$
\Delta V_{1,2}=\Delta V_{2,3}=\cdots=\Delta V_{k-1, k}
$$

is unattainable in realities free market. Thus, fulfillment of condition (7) is considered the situation:

$$
\Delta V_{i, i+1}=\Delta V_{i+1, i+2} \leftrightarrow\left|\Delta V_{i, i+1}-\Delta V_{i+1, i+2}\right| \leq \frac{0.05}{k} \cdot \sum_{i=1}^{k} \Delta V_{k}
$$

The theory of pseudo-radiation local emitters' value of properties with a differential propagation of prices wave subjected to also visual reasoning the correctness assumptions. Based on unit prices of apartments, distributed evenly throughout the area of the analyzed market, was interpolated pseudo wave prices used triangulated irregular network (TIN), which vertices correspond to pointwise deployed offer prices. Tools to constrain TIN and interpolation of pseudo wave prices provides environmental QGIS as well as ArcGIS. As an alternative to triangulated irregular network was selected interpolation wave, describe analyzed occurrence by nearest neighbor method (in ArcGIS) and the method of inverse distance (in QGIS and ArcGIS). It is recognized, that the author's theory is true in terms pseudo-radiation local emitters of property values, when of propagation waves due to existing more than one emitter, and everyone transmitted a signal-prices variously in each direction them propagation. Maintain the theory in part of differential propagation wave prices is observation difference speed increase or decrease offer unit prices between regressive and progressive emitters, as manifested by frequency significant change level these prices.

\section{Empirical Presentation the Conception}

The test material including apartments located in Krakow and belonging administratively to districts: Śródmieście, Krowodrza - the eastern part, Nowa Huta the western part, Podgórze - the northern part. By sample, kriging [11] established for them two regressive emitters: "Rynek Główny" and "Wola Justowska" as well as one progressive emitter named "Podgórze". Kriging results coincide with a real view perception of the market among local society [7]. In ArcGIS environmental was simulated the process of radial propagation wave prices for varying length $\left(\lambda_{i}\right)$. Their autonomic propagation is shown in Figure 1 with signature $(+)$ localization representative properties od established offer prices.

To verify the theory of pseudo-radiation local emitters' value of properties with a differential propagation of prices wave used ArcGIS statistics (juxtaposition in Tables 1-3) consolidation for all emitters and integrated it with single plane cross-section of average prices observed in the individual waves. 


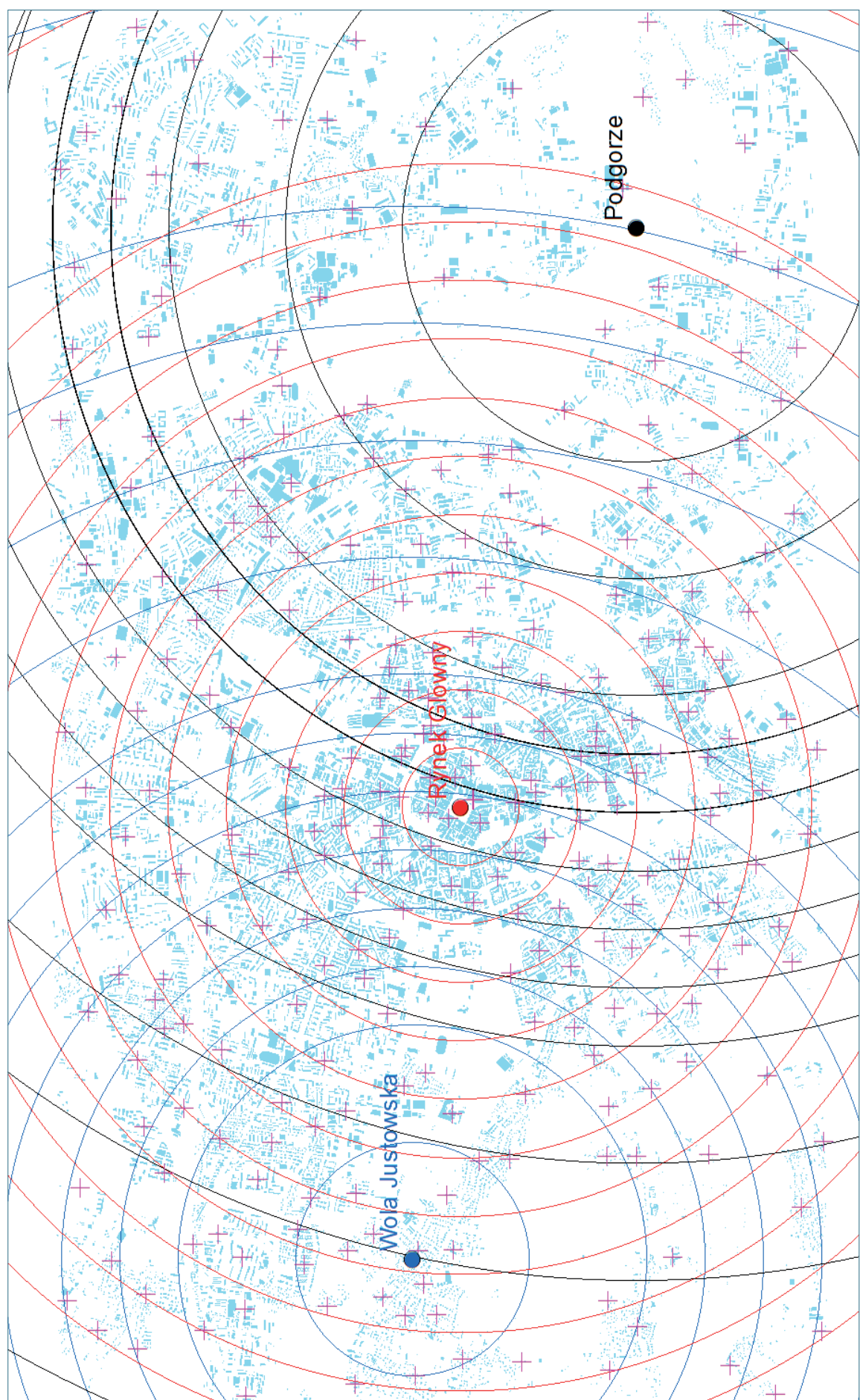

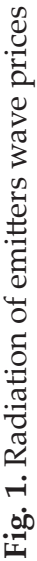




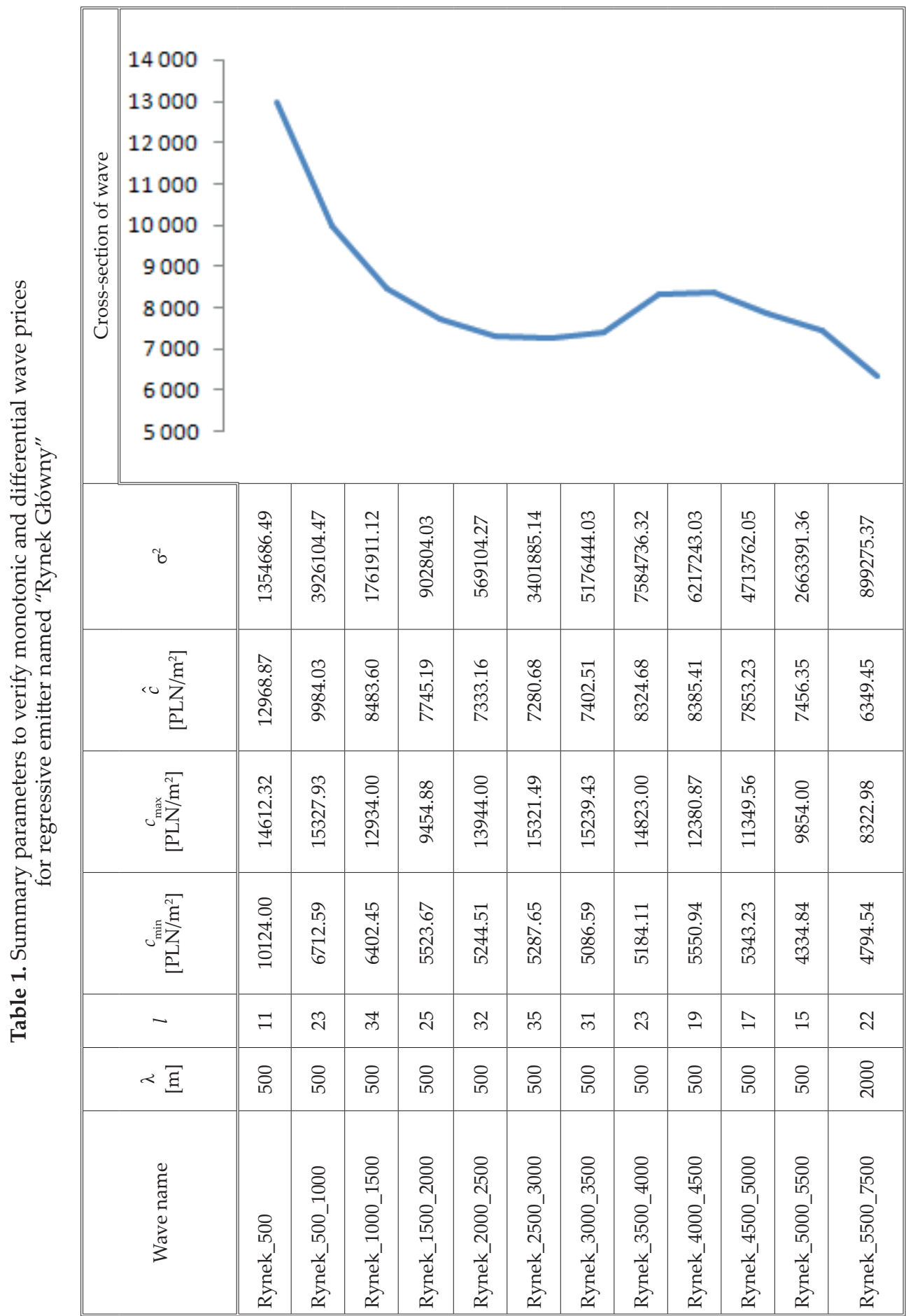




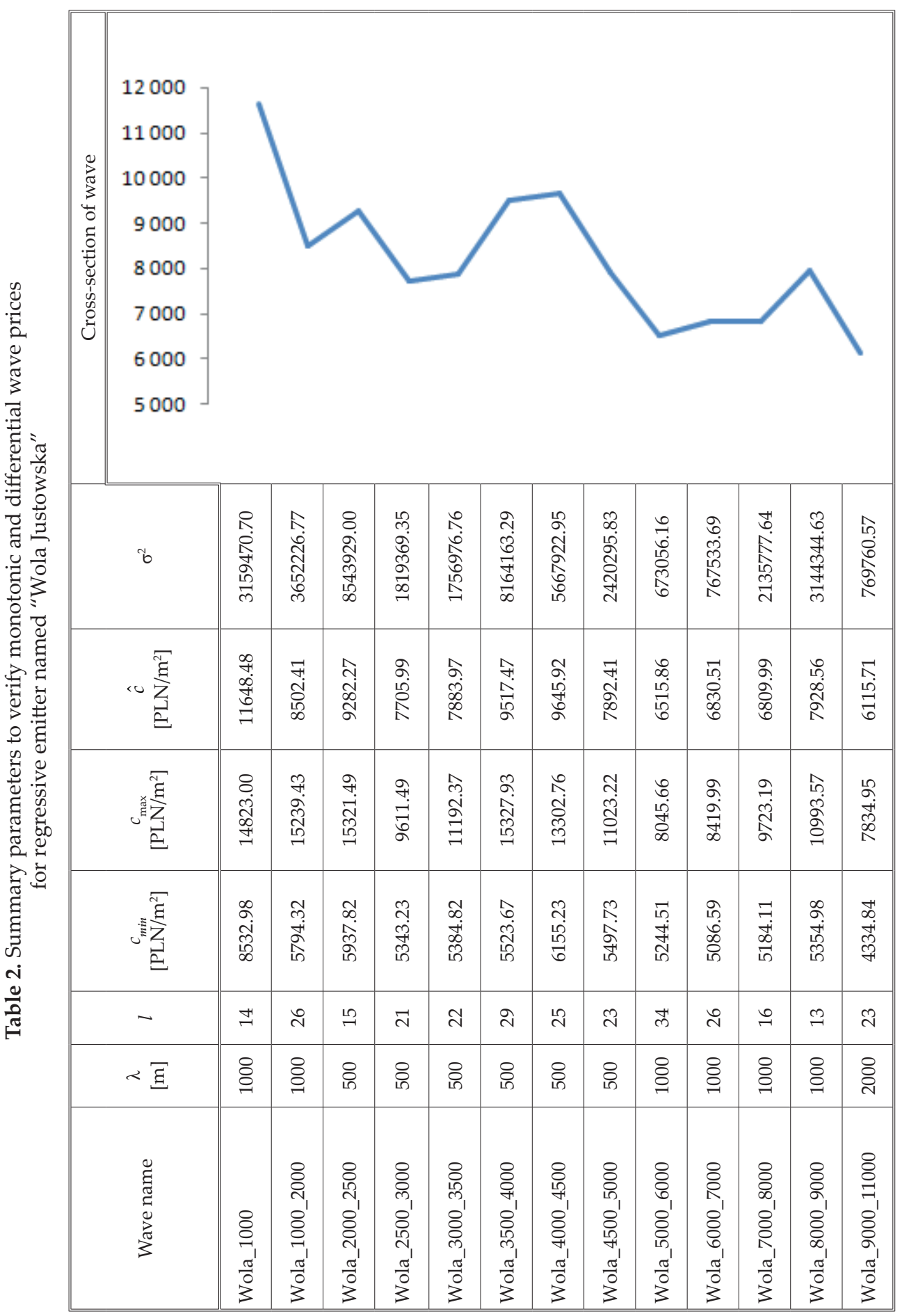




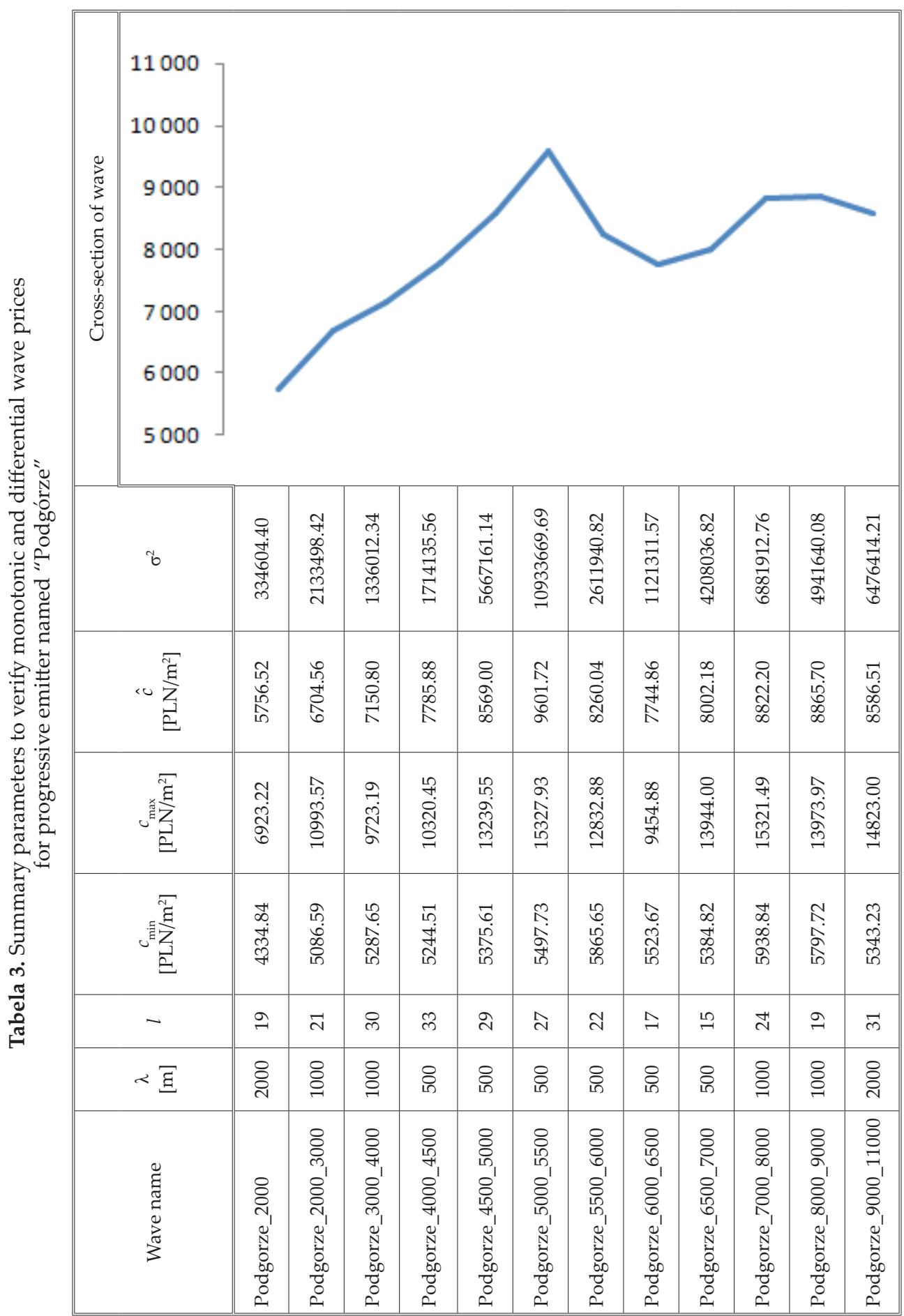


Average unit prices of apartments, on analysis property market, exhibit high variability in successive waves transmitted radially form emitters. Based on juxtaposed in Tables 1-3 results derive conclusion, that regressive emitters accompanied greater and faster change of prices in early phase propagation than progressive emitters. Evidenced by the difference between and "Podgórze" because emits waves of extreme volatility in level 1341.68 PLN/m², "Rynek Główny" and "Wola Justowska" in levels, accordingly $2984.84 \mathrm{PLN} / \mathrm{m}^{2}$ and $3146.07 \mathrm{PLN} / \mathrm{m}^{2}$. These mean, that on the analyzed market are large areas of lower, but stable prices and are opposite for the less numerous apartments in prestige districts. Based on the obtained empirical results maintain in entirety thesis, that propagation emits wave prices is not uniform and not of homogenous development trends. Not uniform revealed a lack of harmonized differences averages unit prices observed in neighboring waves. It is also cause not homogenous development trends, because transmission price signal from emitters "Rynek Główny" and "Wola Justowska" does not correspond with equation (3). Progressive emitter "Podgórze" moreover is not subject to equation (4). Quantitative data confirmed in Tables 1-3, which in the last columns visualization single plane cross-section of wave prices. It shows, that volatility offer prices of apartments is not monotonic, especially in the case adopted as an authoritative source signal emitter "Wola Justowska".

As a result comparison dispersion coefficients $\left(\Delta V_{i, i+1}=\Delta V_{i+1, i+2}\right)$, with accepted $5 \%$ tolerance mismatch, it is stated fulfillment condition (6). These mean, that also true is the conception in part on differential propagation wave prices.

The conducted research allows for the conclusion, that imbalance variance depends mainly on the distance of emitted wave prices relative to the emitter. The larger diameter in case radiation propagation, in wave range included more diverse real estates, i.e. with different functional or technical parameters or localization advantages. For example is composition wave of length $\lambda_{8}=500 \mathrm{~m}$, away from the emitter "Rynek Główny" $3500 \mathrm{~m}$, included both extreme expensive properties located in Wola Justowsja as well as minimalistic apartments (in border analyses market) locate in districts Nowa Huta (western part) and Podgórze (northern part). In such a contrast regions dominate diametric types of real estates, with different standard, workmanship, surrounding and others market characteristics. That anomalies lower quality estimation averages unit prices in range individual waves, which is mapped in relative high variance prices. The aim of increasing accuracy analyzes planes to transition from offer prices to transaction prices contained in notarial acts. This will also reduce specific characteristics technical-functional real estates from peeled segment market.

Enriching quantitative assessment, the theory is visual assessment study area for detection potential emitters wave prices, because it was assumed they polycentric existing and differential propagation caused by allocation epicenters prices in medium disturbed (emitters interact witch each other). 
Below are presented the visualization of propagation waves based on:

- triangulated irregular network (Fig. 2), realized in the environmental ArcGIS and QGIS,

- nearest neighbor method (Fig. 3), realized in the environmental ArcGIS,

- inversed distance method (Fig. 4), realized in the environmental ArcGIS and QGIS.

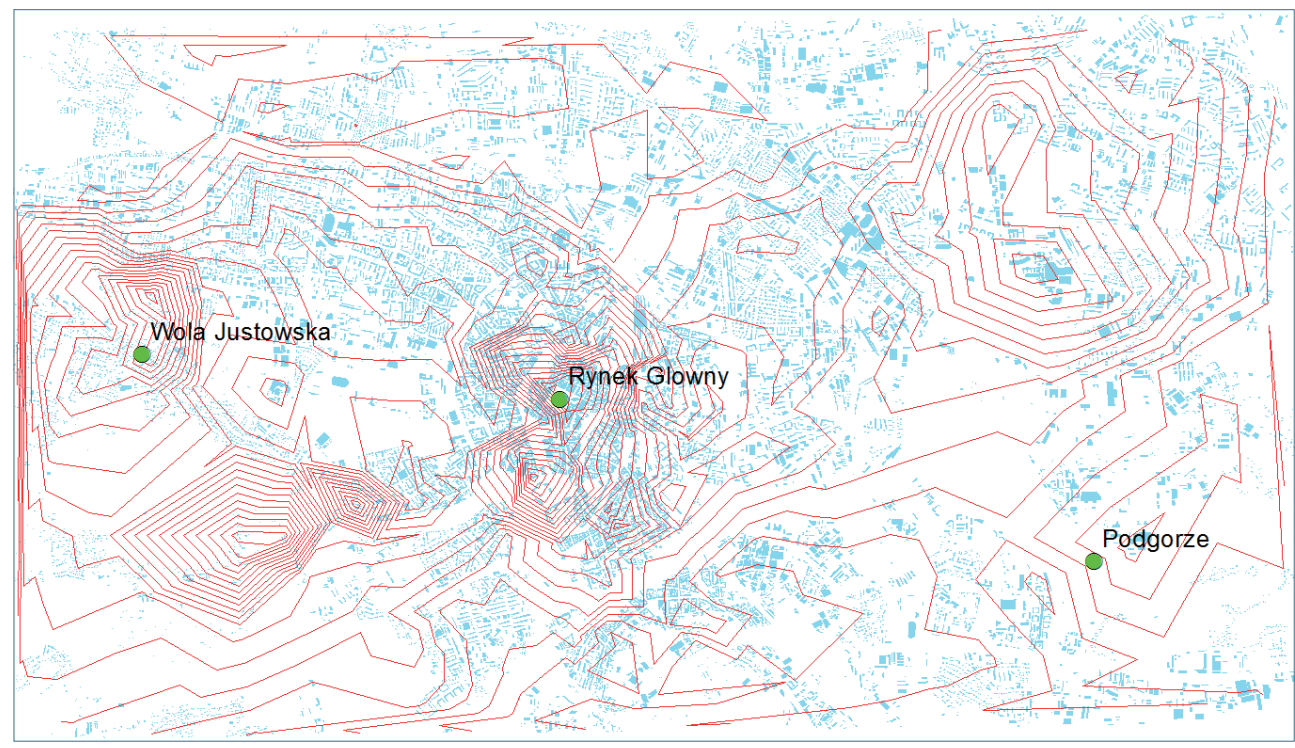

Fig. 2. Propagation wave prices based on TIN

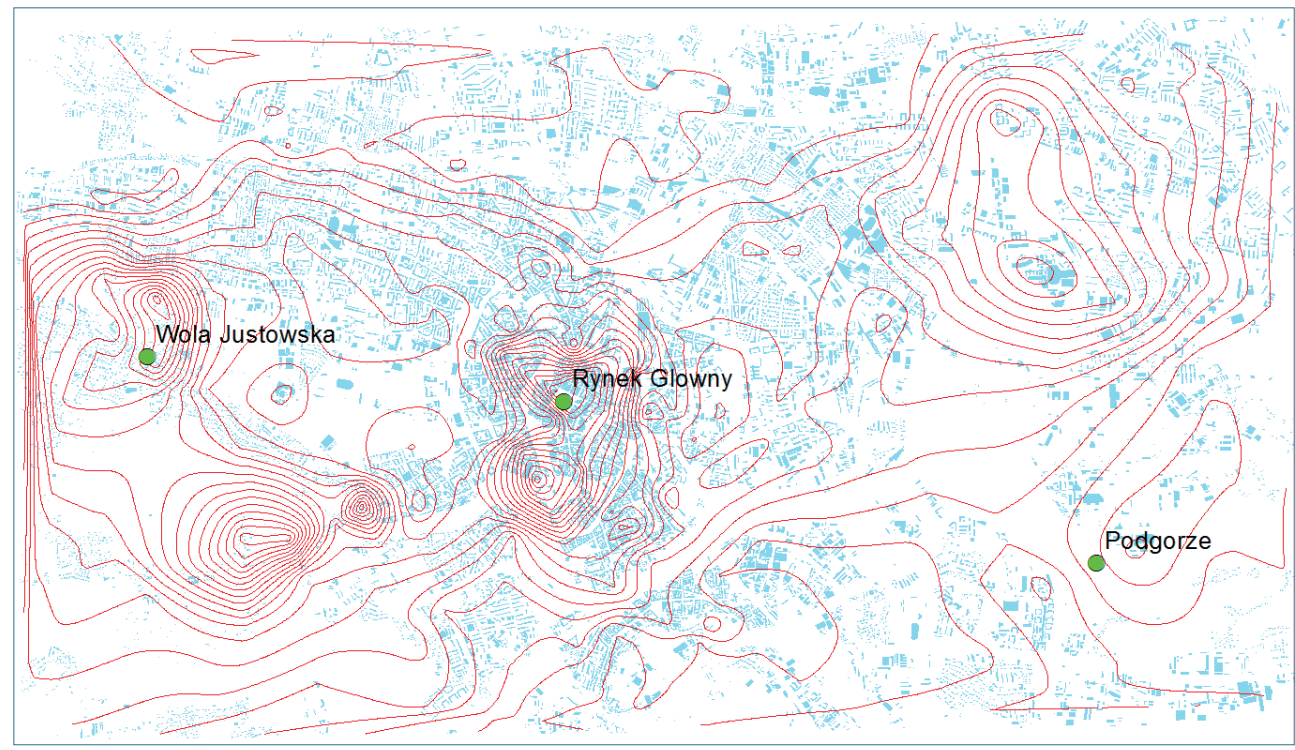

Fig. 3. Propagation wave prices based on the nearest neighbor method 


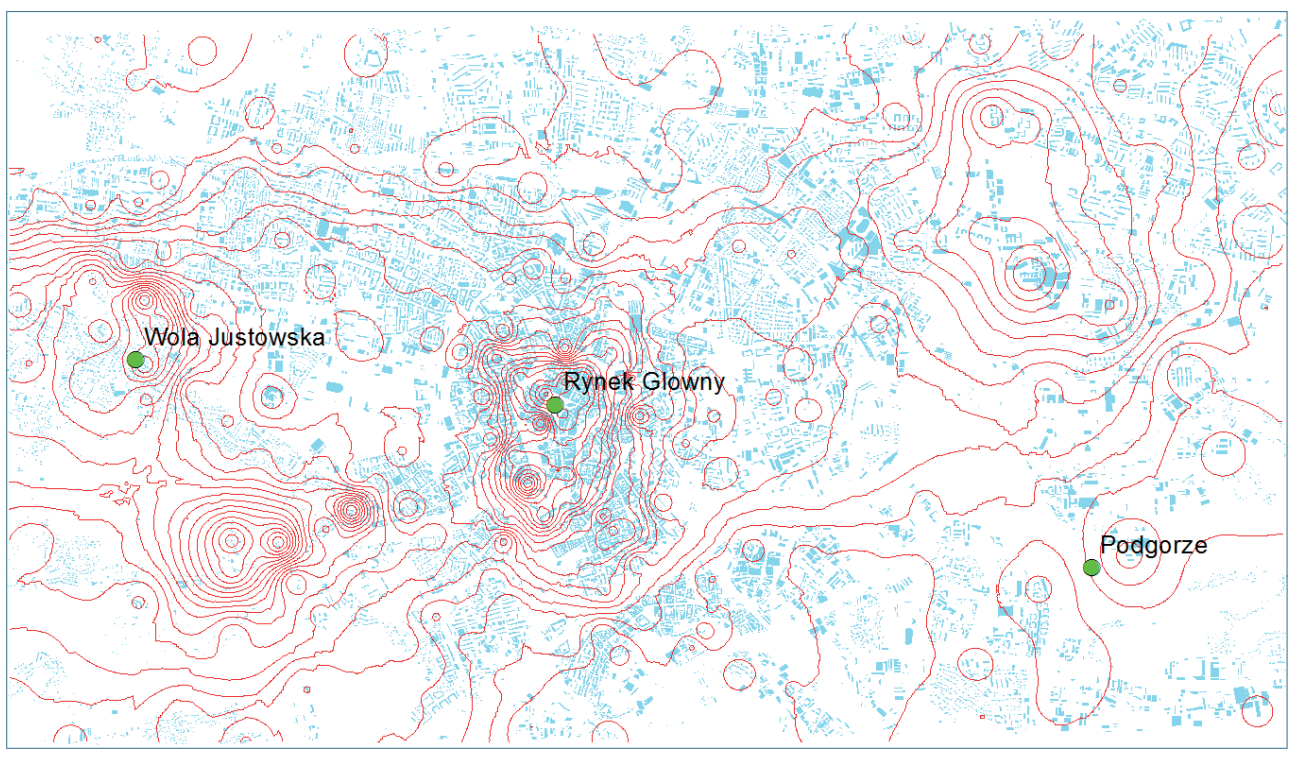

Fig. 4. Propagation wave prices based on inverse distance

Diagnosing Krakow's real estate market, in environmental ArcGIS and parallel in QGIS, focusing on detection potential emitters, proves the existence five regressive price polarizers. Both algorithms, nearest neighbor such as triangulated irregular network, show them clearly without possibility of misinterpretation. However, in both methodologies establishing progressive emitters is difficult due to sheer size areas with relatively low, but stability offer prices. Distribution waves prices according to inverse distance algorithm interpolating, is with excessive precision, taking into account specific cases without its necessary generalization. Extreme object treated like individual emitters with low transmission potential. This reduced accuracy fits hypothetical price polarizers. Beyond the algorithmic divide waves prices are speed and direction them propagation. Against the background regressive emitters shows pseudo-radiation model prices distribution in complex spatial structures. Moreover proven, quantitatively and visual, differential distribution waves prices gives future studies a new trend, covering comparison taken issue with mechanic distribution waves on water assuming exist invariant island prices.

\section{Conclusions}

On the pages of this study presented the theory of pseudo-radiation local emitters' value of properties with a differential propagation of prices wave. Gathered test material from Krakow's real estate market applies apartments, proved multitude polarizers prices with bipolar specify signal transmission. Can distinguish 
regressive emitters, relatively easy to identify by the nearest neighbor method (available in ArcGIS) and triangulated irregular network (available in ArcGIS and QGIS). Can distinguish also progressive emitters, which interpolation is hinders stabilization lower level of prices in a wide area analyses. Pseudo-radiation of polarizers has been proved by reveal lack monotonicity of distribution of offer unit prices observed in individual waves with variable lengths. Proven also, that is the appropriate understanding variable prices in waves as a differential succession uncorrelated their levels in multifactorial (poly-polarization) medium spectral, because the difference between dispersion coefficient tangent waves (compared in pairs), and imposed a $5 \%$ tolerance mismatch, do not equal. It has been shown, that early speed of signal propagation from regressive emitters, in the first phase growing the fastest, but further is strong suppressed. Progressive emitters are more stable. Price waves are limited lower amplitude, which reflected in small variability prices and less sensitive to extreme regions (districts).

In conclusion, the research process, sustain entirely the author's theory of pseudo-radiation local emitters' value of properties with a differential propagation of price waves. The authors also recognize the possibility of further development through equalization representative properties describe market characteristics and transaction prices as well as linking taken issue with rules of mechanic distribution waves on water mirror. Theory proposed by the authors is basis for further analysis aimed at creating idea to modeling market or cadastral values of real estates in any market segment.

\section{References}

[1] Anselin L., Florax R., Rey S. (eds.): Advanced in Spatial Econometrics. Methodology. Tools and applications. Springer-Verlag, Berlin 2004.

[2] Cellmer R., Kuryj J.: Określenie stref o podobnej cenności gruntów z wykorzystaniem metod geostatystycznych. Studia i Materiały Towarzystwa Naukowego Nieruchomości, vol. 19, nr 3, 2011, pp. 7-18.

[3] Cichociński P.: Porównanie metod interpolacji przestrzennej w odniesieniu do wartości nieruchomości. Studia i Materiały Towarzystwa Naukowego Nieruchomości, vol. 19, no. 3, 2011, pp. 119-132.

[4] Czesak B.: Koncepcja systemu informacji geograficznej wspomagajacego wyceny nieruchomości w nawiazaniu do niemieckiego systemu BORIS plus. Infrastruktura i Ekologia Terenów Wiejskich, no. 2012/3, pp. 37-47.

[5] Domański R.: Gospodarka przestrzenna: podstawy teoretyczne. WN PWN, Warszawa 2007.

[6] Getis A., Mur J., Zoller H. (eds.): Spatial Econometrics and Spatial Statistics. Palgrave Macmillan, New York 2004. 
[7] Głuszek M., Krochmal P.: Popyt i preferencje mieszkaniowe w Krakowie IV kwartał 2014. Instytut Analiz Monitor Rynku Nieruchomości mrn.pl, Kraków 2014.

[8] Hermann B.: Czynniki kształtujące wartość nieruchomości w kontekście dokumentów planistycznych, [in:] Skutki finansowe planowania przestrzennego - konsekwencje dla rozwoju, Poznań 2013 [proceedings paper].

[9] International Valuation Standards 2013. Framework and Requirements. International Valuation Standards Council, [on-line:] www.ivsc.org [access: 30.01.2016].

[10] Kozioł-Kaczorek D., Pietrzykowski R.: Analiza cen nieruchomości z wykorzystaniem statystyki Morana. Studia i Materiały Towarzystwa Naukowego Nieruchomości, vol. 19, nr 3, 2011, pp. 182-191.

[11] Ligas M., Kulczycki M.: Kriging approach for local height transformations. Geodesy and Cartography, vol. 63, no. 1, 2014, pp. 25-37.

[12] Pietrzykowski R.: Analiza przestrzenna rynku nieruchomości rolniczych z uwzględnieniem wpływu czynników ekonomicznych. Studia i Materiały Towarzystwa Naukowego Nieruchomości, vol. 19, nr 3, 2011, pp. 217-227.

[13] Pietrzykowski R.: Przestrzenne ujęcie rynku nieruchomości mieszkaniowych w latach 2007-2010. Finanse, Rynki Finansowe, Ubezpieczenia, nr 29, 2010, pp. 97-107.

[14] Suchecki B.: Ekonometria przestrzenna. Metody i modele analizy danych przestrzennych. C.H. Beck, Warszawa 2010.

[15] Thrall G.I.: GIS Applications in Real Estate and Related Industries. Journal of Housing Research, vol. 9, no. 1, 1998, pp. 33-59.

[16] Żelazowski K.: Regionalne zróżnicowanie cen i ich determinant na rynku mieszkaniowym $w$ Polsce. Studia i Materiały Towarzystwa Naukowego Nieruchomości, vol. 19, nr 3, 2011, pp. 97-107. 